\title{
Radioisotope Reduction Using Solar Power for Outer Planetary Missions
}

James Fincannon

Glenn Research Center, Cleveland, Ohio 


\section{NASA STI Program . . . in Profile}

Since its founding, NASA has been dedicated to the advancement of aeronautics and space science. The NASA Scientific and Technical Information (STI) program plays a key part in helping NASA maintain this important role.

The NASA STI Program operates under the auspices of the Agency Chief Information Officer. It collects, organizes, provides for archiving, and disseminates NASA's STI. The NASA STI program provides access to the NASA Aeronautics and Space Database and its public interface, the NASA Technical Reports Server, thus providing one of the largest collections of aeronautical and space science STI in the world. Results are published in both non-NASA channels and by NASA in the NASA STI Report Series, which includes the following report types:

- TECHNICAL PUBLICATION. Reports of completed research or a major significant phase of research that present the results of NASA programs and include extensive data or theoretical analysis. Includes compilations of significant scientific and technical data and information deemed to be of continuing reference value. NASA counterpart of peer-reviewed formal professional papers but has less stringent limitations on manuscript length and extent of graphic presentations.

- TECHNICAL MEMORANDUM. Scientific and technical findings that are preliminary or of specialized interest, e.g., quick release reports, working papers, and bibliographies that contain minimal annotation. Does not contain extensive analysis.

- CONTRACTOR REPORT. Scientific and technical findings by NASA-sponsored contractors and grantees.

- CONFERENCE PUBLICATION. Collected papers from scientific and technical conferences, symposia, seminars, or other meetings sponsored or cosponsored by NASA.

- SPECIAL PUBLICATION. Scientific, technical, or historical information from NASA programs, projects, and missions, often concerned with subjects having substantial public interest.

- TECHNICAL TRANSLATION. Englishlanguage translations of foreign scientific and technical material pertinent to NASA's mission.

Specialized services also include creating custom thesauri, building customized databases, organizing and publishing research results.

For more information about the NASA STI program, see the following:

- Access the NASA STI program home page at http://www.sti.nasa.gov

- E-mail your question via the Internet to help@ sti.nasa.gov

- Fax your question to the NASA STI Help Desk at 301-621-0134

- Telephone the NASA STI Help Desk at 301-621-0390

- Write to: NASA Center for AeroSpace Information (CASI) 7115 Standard Drive Hanover, MD 21076-1320 
NASA/TM-2008-215437

\title{
Radioisotope Reduction Using Solar Power for Outer Planetary Missions
}

\author{
James Fincannon \\ Glenn Research Center, Cleveland, Ohio
}

Prepared for the

Sixth International Energy Conversion Engineering Conference (IECEC)

sponsored by the American Institute of Aeronautics and Astronautics

Cleveland, Ohio, July 28-30, 2008

National Aeronautics and

Space Administration

Glenn Research Center

Cleveland, Ohio 44135 
Trade names and trademarks are used in this report for identification only. Their usage does not constitute an official endorsement, either expressed or implied, by the National Aeronautics and Space Administration.

Level of Review: This material has been technically reviewed by technical management.

Available from

NASA Center for Aerospace Information 7115 Standard Drive

Hanover, MD 21076-1320
National Technical Information Service 5285 Port Royal Road Springfield, VA 22161

Available electronically at http://gltrs.grc.nasa.gov 


\title{
Radioisotope Reduction Using Solar Power for Outer Planetary Missions
}

\author{
James Fincannon \\ National Aeronautics and Space Administration \\ Glenn Research Center \\ Cleveland, Ohio 44135
}

\begin{abstract}
Radioisotope power systems have historically been (and still are) the power system of choice from a mass and size perspective for outer planetary missions. High demand for and limited availability of radioisotope fuel has made it necessary to investigate alternatives to this option. Low mass, high efficiency solar power systems have the potential for use at low outer planetary temperatures and illumination levels. This paper documents the impacts of using solar power systems instead of radioisotope power for all or part of the power needs of outer planetary spacecraft and illustrates the potential fuel savings of such an approach.
\end{abstract}

\section{Introduction}

Radioisotope power systems (RPS) have been used on past outer planetary space missions very successfully. The benefits of these power systems are clear; they have low mass and are very compact. The technology push to make such systems more efficient enhances their ability to perform more missions for a given amount of radioisotope fuel. If there were no limitations on the availability of the fuel for such power systems, then RPS would be the obvious choice for all future outer planetary missions. Unfortunately, radioisotope fuel production is limited and requires a very significant investment of resources to assure a substantial supply for use by space, academic, and commercial customers. It is possible to use large amounts of such fuel for lunar and Mars unmanned/manned rovers/mobile assets, manned bases, unmanned observation stations, as well as landers/rovers on other small bodies/moons/planets (e.g., Europa, Venus) and, of course, the typical outer planetary uses. In order to assure access to the outer planets and to conserve limited radioisotope fuel for missions that absolutely require it, it is important to assess the ability of solar power to partially, or perhaps completely, replace the power provided by RPS for some missions.

\section{Past Work}

Various spacecraft (Rosetta, Juno, INSIDE) demonstrate the feasibility of using solar power for outer planetary missions (i.e., at or beyond Jupiter). Past analyses (circa 1968) have shown the combination of solar with electric propulsion provided a feasible alternative for a mission to Jupiter (ref. 1) where solar power in Jupiter orbit was used instead of RPS. Other solar powered spacecraft at Jupiter or near its orbit include Rosetta (ref. 2) which has already launched and Juno (ref. 3) which is still in development. Rosetta is planned to reach 5.25 AU, which is approximately the distance of Jupiter, but will not enter orbit. Juno is planned to reach 5.5 AU and enter a highly elliptical Jupiter polar orbit at $\sim 39$ planetary radii permitting a greatly reduced operational period within the main radiation belts. Rosetta and Juno use traditional planar solar arrays, although Rosetta uses silicon solar cells and Juno is planning on using triple junction cells. The INSIDE spacecraft (ref. 4) for Jupiter operation was proposed to use triple junction lightweight solar arrays and low power operation $(90 \mathrm{~W})$ in an orbit to avoid the worse radiation belts. Solar arrays (a larger area) were also proposed for a version of the INSIDE spacecraft (ref. 5) for operation as a atmospheric probe deployment flyby vehicle to Saturn, again, using the excess solar power with electric propulsion early in the mission. For Cassini (ref. 6), a study was performed to justify the use 
of radioisotope power by considering solar arrays. This option was not accepted mainly because the mission power level was high enough to require very large solar arrays. Also, because the traditional approach of planar solar array design at that time, the mass/size of the power system was considered prohibitive, which restricted the launch vehicle, and limited deployed maneuvering. Other concerns were the inclusion of solar array moving parts which could affect reliability and safety. Apart from solar arrays, another approach for deep space power has been proposed to use solar light-to-heat concentrators with engines (such as Stirling) (refs. 7 and 8).

\section{Analysis Methods}

Ideally, it would be desirable to devise complete set of useful missions for various outer planetary distances (from Jupiter to Uranus) in order to evaluate the net benefits of solar power (partially or completely) replacing radioisotope power. This would require knowledge of mission goals, realistic instrument sets/operational modes to achieve those goals, and power requirements of the remaining spacecraft subsystems. Launch vehicles, use of solar electric propulsion and/or gravity assists, and cost could be assessed. Essentially, this would be a complete, preliminary spacecraft design. Due to its complexity and the limited resources available, this approach was not taken. Rather, using a spreadsheet tool, a model was developed which allowed the mass of the power system to be estimated as a function of distance from the Sun. The heliocentric distances at which the power systems were sized for this paper were $\sim 5$ AU (Jupiter), $\sim 10$ AU (Saturn), and $\sim 20$ AU (Uranus). Various combinations of state-of-the-art and projected solar arrays and solar cells were used. The solar array types included Ultraflex (refs. 9 and 10), Planar Squarerigger (ref. 9) and Stretched Lens Array Squarerigger (refs. 9, 11 to 14). The solar cell types included state-of-the-art (SOA) triple junction gallium arsenide cells and projected IMM (Inverted Metamorphic) cells.

A critical aspect of this analysis is the solar cell efficiency under low-intensity, low-temperature (LILT) conditions. Various reports have documented testing of solar cells under these conditions (refs. 15 to 19); however, they focused on a distance of 1 to $5 \mathrm{AU}$ with most work focusing on silicon cells. Since the best SOA cells for these outer planetary missions were likely to be triple junction type, test data was acquired at NASA Glenn Research Center for such cells under a variety of solar intensities and temperatures (up to $22 \mathrm{AU}$ ) (refs 20 and 21). The effect of solar intensity and temperature was modeled based on this data. Projected cells were assumed to have an added 5 percent efficiency from SOA values. Although the SOA solar cell options assumed triple junction cell mass characteristics, and the projected solar cell options were based on the very thin IMM solar cell mass characteristics. Cell temperatures assumed for this paper were $-134{ }^{\circ} \mathrm{C}$ (at Jupiter's distance), $-173{ }^{\circ} \mathrm{C}$ (at Saturn's distance), and $-202{ }^{\circ} \mathrm{C}$ (at Uranus' distance).

The duration at different distances from the Sun, as well as the total flight time, affect the power system degradation. These durations are functions of the mission design. The various mission design approaches include direct trajectory, (multiple) Earth and/or Venus gravity assist, and the use of chemical stages and/or solar electric propulsion (SEP) and radioisotope electric propulsion. For this paper, multiple Venus/Earth gravity assist times were assumed amounting to $2.5 \mathrm{yr}$ with a SEP mission. Mission transit times after the gravity assist period was assumed to be based on $2 \mathrm{AU} / \mathrm{yr}$. Mission duration after transit was assumed to be $2 \mathrm{yr}$ (i.e., heliocentric space only). Because the solar array was sized to provide a specific power level near the end of its mission at a low intensity illumination, closer to the Sun, a much higher power level is provided. Either the excess power is unused (e.g., remains on solar array, the solar array off-pointed, or solar cells operated at poor efficiency using peak power tracking) or the power can be used for SEP. In any case, only a small amount of available power early in the mission is needed by the primary spacecraft bus.

Degradation of power due to radiation, micrometeoroids, ultraviolet radiation, thermal cycling, contamination, cell mismatch, and radiation damage were assessed. Damage factors (other than from radiation) added up to 1.4 to 3.1 percent of the total degradation for the missions considered. Radiation damage ranged from 10 percent (interplanetary only) to 30 percent (Jupiter orbiting). Ultraviolet 
darkening, micrometeoroid, thermal cycling, and contamination are all very small when averaged over the entire mission. Using gravity assists increases the amount of time at distances with higher ultraviolet radiation darkening and radiation resulting in higher degradations. For radiation, the degradation is 7 percent for a direct interplanetary trajectory but using SEP with gravity assists the degradation is 10 percent and using a chemical stage with gravity assists is increased by 12 percent. Off-pointing of the solar arrays or increasing the coverglass thickness may reduce these impacts. Temperature of the solar array can also increase greatly near Venus and drag/orbital debris may be a problem for close gravity assists. It is assumed that solar array off-pointing can minimize the impact of these effects. A higher voltage ( $>90 \mathrm{~V})$ SEP-related degradation (not considered in this study) is the result of SEP induced local plasma around the spacecraft which can lead to large parasitic electron current collection by the solar array's exposed solar cell conductors (typical for Ultraflex-type solar arrays with open solar cell back contacts). Various design measures, which add mass, can be taken to reduce the substantial current loss caused by this kind of degradation.

Solar array areal densities were $1.59 \mathrm{~kg} / \mathrm{m}^{2}$ (Ultraflex-SOA), $0.90 \mathrm{~kg} / \mathrm{m}^{2}$ (Ultraflex-Projected), 2.08 $\mathrm{kg} / \mathrm{m}^{2}$ (Planar Squarerigger-SOA), $1.39 \mathrm{~kg} / \mathrm{m}^{2}$ (Squarerigger-Projected), $0.85 \mathrm{~kg} / \mathrm{m}^{2}$ (SLASR-SOA), and $0.75 \mathrm{~kg} / \mathrm{m}^{2}$ (SLASR-Projected). Each option assumed the minimal, 3 mil coverglass thickness, which is the mass optimum value for low radiation dosage missions (for the SLASR option and more radiation, thicker coverglasses may provide a lower mass system). The "SOA" and "Projected" terms apply mainly to solar cell type, both their efficiency and areal mass characteristics. For the "Projected" options, the areal mass savings of the solar cell design (IMM type) but not solar array structural reductions which result from lower mass solar cells because such estimates require detailed analysis. Ultraflex solar arrays are assumed to be scalable from 4 to $6 \mathrm{~m}$ in diameter for the "SOA," and up to $8 \mathrm{~m}$ in diameter for the "Projected" application. Planar Squarerigger and SLASR solar arrays are based on 2.5- by 5-m bays (the fundamental solar array building block size, which have been tested on ground and are considered likely to be mass optimum). Bays can be connected to each other to build up a wing. It is assumed that other bay sizes may be possible depending on the mission.

For the flyby-type of missions, energy storage was required for the launch energy needs (i.e., $2 \mathrm{hr}$ at nominal power prior to solar array deployment) and for peak loads (orbiting spacecraft would likely require more energy storage). The battery was assumed to be a lithium ion type with $80 \mathrm{~W}-\mathrm{hr} / \mathrm{kg}$, 80 percent depth of discharge, and 90 percent energy storage charge/discharge efficiency. Since the mission was assumed to be a flyby-type (i.e., low radiation exposure and minimal eclipse operation), the depth of discharge was assumed to be valid for very low cycles of use $(<10)$ and for mission phases such as launch/deployment, off-pointing periods, and gravity-assist eclipse periods, possibly at reduced power. Missions with significant and frequent eclipses due to the planet, rings, moons, may require lower battery depth of discharges, thus larger batteries.

Harness, power management, gimbals, and energy storage masses were calculated separately. Gimbals were assumed to be two axis tracking and $840 \mathrm{~W} / \mathrm{kg}$ (power level is the solar array power at beginning of mission). The solar array interface structure (including tie downs, secondary boom, and structure) was assumed to be $2910 \mathrm{~W} / \mathrm{kg}$ (power level is the solar array power at beginning of mission). The solar array harness from gimbal to switching unit was assumed to be $1689 \mathrm{~W} / \mathrm{kg}$ (power level is the solar array power at beginning of mission). These values were derived from Ultraflex designs from the Orion spacecraft. The other non-solar array spacecraft harness was assumed to be 25 percent of the electronics mass. The power distribution unit was assumed to be $40 \mathrm{~W} / \mathrm{kg}$ (power level is the spacecraft bus power at end of mission). The peak power tracker/regulator unit and the battery charge/discharge unit were each assumed to be $40 \mathrm{~W} / \mathrm{kg}$ (power level is the solar array power at the end of mission). These units were based on the Venus Express/Mars Express/Rosetta design adjusted to handle higher solar array voltages (ref. 22).

Solar array (pointing, failed strings, blocking diodes, interconnect efficiency, solar array harness efficiency) and power system (harness losses, peak power tracker accuracy, regulator efficiency, power distribution unit efficiency, switchgear efficiency) losses accounted for a $\sim 17$ percent reduction in power. 
Characteristics of the RPS assumed for this study was the Advanced Stirling Radioisotope Generator (ASRG) as cited in reference 23. This RPS was selected because it has the lowest mass and used the lowest amount of radioisotope fuel ( $\sim 1 \mathrm{~kg}$ of plutonium- 238 for one ASRG, i.e., 2 general purpose heat sources). The mass for the ASRG was assumed to be $23 \mathrm{~kg}$. When determining the net mass for the RPS system in this analysis, a battery and a battery charge and discharge regulator for load leveling and peak power use was included as well as individualized harness and power distribution assemblies; an additional $16 \mathrm{~kg}$. Other masses that may be required include a stand-off mast and /or thermal heat shield to attach the RPS to in order to reduce heat rejection onto the spacecraft. Some projected technology advancements of the ASRG, not reflected in this study, are planned to increase the power and lower the mass (12 and -17 percent respectively).

Concentrator, heat engine options were not considered in the study because of perceived pointing issues.

The missions depicted in this paper's results were for spacecraft at distances representing Jupiter, Saturn, and Uranus, essentially flyby missions. Missions requiring orbit insertion or rendezvous add complexity and mass. Reference 21, which documents other results using the model described in this paper, presents results of these kind of mission operations for Jupiter/Europa, Uranus, Saturn, and two Centaur-class asteroids. Depending on the orbit characteristics, the energy storage size may be significant. Orbit insertion may require off-pointing of a solar array for various reasons (e.g., to minimize dust impacts when passing through a ring, to point a thruster, to minimize structural loads on the solar arrays, or aim instruments) which may affect energy storage size. Shadowing due to rings or moon passes may also affect energy storage size. Recharge time, energy storage requirements, and operational requirements (e.g., powering down during shadows or payload operation) impact the size of the solar array. For orbiting spacecraft, the cell temperatures become a function of planetary and moon infrared/albedo heat contributions. Other effects of planetary orbiting include radiation degradation of solar cells as well as ionizing radiation on various electronics. The radiation in Jupiter, Saturn, and Uranus orbit is dramatically different, but requires the knowledge of orbit definition and mission duration to assess the impact.

\section{Analysis Results}

Figures 1 and 2 illustrate the effect on mass and area of using solar power to replace a "unit" of RPS power to save radioisotope fuel. This is the solar power system that must be added to replace one ASRG RPS unit which uses $\sim 1 \mathrm{~kg}$ of plutonium-238. Based on an assumed mission timeline and radioisotope fuel heat degradation, the power level of the ASRG RPS was assumed to be $135 \mathrm{~W}$ at $5 \mathrm{AU}, 133 \mathrm{~W}$ at $10 \mathrm{AU}$, and $128 \mathrm{~W}$ at $20 \mathrm{AU}$. For example, at Uranus ( 20 AU), the power system mass must increase by $541 \mathrm{~kg}$ (i.e., $580 \mathrm{~kg}$ added for the SOA Ultraflex solar power, battery, etc and $39 \mathrm{~kg}$ subtracted for the ASRG RPS, battery, charge-discharge unit, etc.). If the spacecraft power is only $128 \mathrm{~W}$ at $20 \mathrm{AU}$, then this implies that it takes $541 \mathrm{~kg}$ of solar power mass to replace the entire RPS. If the power level is higher than specified (e.g., $128 \mathrm{~W}$ at $20 \mathrm{AU}$ ), then either multiples of mass and area impacts can be determined or hybrid combinations of the solar and RPS power systems be determined. Using better power system technology and lowering the user power level by improving the payload technology or changing its operational design (as discussed in the following section) can reduce the size of the solar power system although the proportional savings of radioisotope fuel remains the same. In other words, if the power level is halved, although the solar power system would be half its mass, the RPS would use half the radioisotope fuel, so such a lower fuel usage could be more acceptable, depending on fuel availability. The feasibility of spacecraft with very high power system masses (such as for Uranus distances) depends upon the launch vehicle, but such masses and areas certainly encourages the improvement of solar power system technology (as well as lowering power levels).

Figure 3 shows how much various technology improvements can increase the power for a fixed mass for the location of a Saturn flyby. The mass of the solar power system is assumed to be equal to the ASRG RPS power system. Improving the cell and array technology have the potential to double the power output from the solar power system. 
There are a number of typical uncertainties that are inherent in this level of analysis. The study assumed a best engineering estimate of the input data, but a more appropriate approach would be to assign probability ranges. These uncertainties can be grouped into four areas: mission, hardware modeling, environment, and projected technology uncertainty. Mission uncertainty includes orbit altitude, trip time and science mission duration, launch date, instrument suite, and instrument requirements. These factors affect how long a spacecraft is in a high radiation zone, spacecraft orientation/solar arrays tracking (use scanning platform or move spacecraft), length of eclipse period, power levels for insolation and eclipse, and the loading on solar arrays due to thruster firings. The data presented in this paper assumed the missions were outside a planetary radiation zone, with either no eclipse period or low power levels for eclipse. Hardware modeling uncertainty is a function of the simplified modeling method normally used in early sizing analyses for spacecraft power system hardware. This involves simplified scaling of a number of components including gimbals, structures, power management and control, and power distribution and harness. Also, long term, low temperature effects on solar cells has not been experimentally verified. Environment uncertainty includes knowledge of the radiation environment at outer planetary bodies (e.g., Uranus), effects of long duration, low temperature operation on harness/gimbals/other solar array hardware, radiation effects on insulators (dielectric loss/embedded charge) and the effect of long term contamination due to spacecraft outgassing or thruster deposits. Included in this area would be detailed thermal modeling of the spacecraft. RPS has significant waste heat that can be used to keep the spacecraft warm for the low temperatures of outer planetary space. Solar power systems would require a combination of low temperature subsystems (i.e., materials, electronics), radioisotope heater units, and/or electric heaters. Finally, the projected technology uncertainty depends upon funding levels and adaptation of technology in other areas. In this study, only solar array and solar cell technology improvements were considered but improvements may exist in the other areas such as low power and high efficiency electronics in all spacecraft systems and lighter structures. Nominal low temperature, low intensity behavior of projected cells (namely IMM cells) as well as radiation degradation may be significantly different from standard cells.

\section{Future Work}

This analysis may be improved by obtaining a realistic set of missions and sizing the entire spacecraft including all the subsystems. Mission design tied with useful, feasible instruments and payloads including launch vehicles and various propulsion concepts is essential in such an activity.

A focusing on low power usage must be emphasized for outer planetary missions, regardless of power source. This includes duty-cycling power using hardware and using power efficient equipment in the payloads and spacecraft bus. Reference 24 discusses a spacecraft design for a Neptune/Triton mission which emphasizes and assesses low power components. It presents a peak spacecraft power of $37 \mathrm{~W}$ and standby power of $13 \mathrm{~W}$. Although such potentially low operational power levels seem encouraging for spacecraft designs, a great deal depends upon what science data is to be collected, the type of instruments, and their power requirements. References 25 to 28 discuss advances to enable low power devices including those demonstrated on ST-5 and DS-1 (http://nmp-techval-reports.jpl.nasa.gov/ DS1/LPE_Integrated_Report.pdf). The Defense Advanced Research Projects Agency (DARPA) also has performed low technology readiness level work in the area of low energy usage electronics which have the potential for revolutionary advances in spacecraft electronics. These include "clockless logic" circuits (http://www.darpa.mil/ mto/programs/class/index.html) which are data driven and only consume power when doing useful work and "energy starved electronics" (http://www.darpa.mil/mto/programs/ese/index.html) which allow the operation of devices in the very low voltage regime below which circuit devices normally operate and which may result in "100 times improvement in energy per operation". 


\section{Conclusion}

This paper has presented data illustrating the mass and area that must be accommodated in order to use solar power instead of radioisotope power. Although it is clear that RPS is the lowest mass and area solution, in order to enable missions that may be curtailed or eliminated due to lack of radioisotope fuel, it is necessary to investigate other options that have been enabled by lower mass solar arrays and high efficiency solar cells which have the ability to operate in low intensity, low temperature conditions.

\section{References}

1. Loucks, R.E., and Truscello, V., "Power system design for Jupiter solar electric propulsion spacecraft," NASA CR-97196, JPL-TR-32-1347, Oct. 1968.

2. Fiebrich, H., Haines, J.E., and Tonicello, F., "Power System Design of the Rosetta Spacecraft," 2nd International Energy Conversion Engineering Conference, AIAA 2004-5535, Aug. 2004.

3. Matousek, S., "The Juno New Frontiers mission," International Astronautical Congress, IAC-05A3.2.A.04, Oct. 2005.

4. Reitsema, H.J., Smith, E.J., Spilker, T., and Reinert, R., "Significant Science at Jupiter Using Solar Power," Forum on Innovative Approaches to Outer Planetary Exploration 2001-2020/72, LPIContrib-1084, Abstract 4115, 2001.

5. Spilker, T.R., "Saturn Deep Atmospheric Entry Probes Delivered by INSIDE Jupiter Derivative Spacecraft," Forum on Innovative Approaches to Outer Planetary Exploration 2001-2020/79, LPIContrib-1084, Abstract 4113, 2001.

6. "Cassini Program Environmental Impact Statement Supporting Study, Volume 2: Alternate Mission and Power Study," Jet Propulsion Laboratory Publication no. D-11777, Cassini Document no. 699070-2, July 1994.

7. Schreiber, J. G., “A Deep Space Power System Option Based on Synergistic Power Conversion Technologies," 2000 Space Technology and Applications International Forum, NASA/TM-2000210232, Jan. 2000.

8. Mason, L. S., "Solar Stirling for Deep Space Applications," 2000 Space Technology and Applications International Forum, NASA/TM-1999-209656, Jan. 2000.

9. Murphy, D. M., Eskenazi, M. I., White, S. F., and Spence, B. R., "Thin-Film And Crystalline Solar Cell Array System Performance Comparisons," 29th IEEE Photovoltaic Specialists Conference 2002, May 2002.

10. Spence, B. R., Mardesich, N., Peterson, T, et al., "Next Generation UltraFlex Solar Array for NASA's New Millennium Program Space Technology 8," 4th International Energy Conversion Engineering Conference and Exhibit, Jun. 2006.

11. O’Neill, M., Piszczor, M., Brandhorst, H., et al., "Stretched Lens Array Squarerigger (SLASR) Technology Maturation," 19th Space Photovoltaic Research and Technology Conference, Sept. 2005.

12. O’Neill, M., Piszczor, M., Brandhorst, H., et al., "Stretched Lens Array SquareRigger (SLASR): A New Space Array for High-Power Missions," 4th World Conference on Photovoltaic Energy Conversion, May 2006.

13. Piszezor, M.F., O'Neill, M.J., Eskenazi, M.I., and Brandhorst, H.W., "The Stretched Lens Array SquareRigger (SLASR) for Space Power," 4th International Energy Conversion Engineering Conference and Exhibit, Jun. 2006.

14. Brandhorst, H.W., O’Neill, M.J., and Eskenazi, M.I., "Update for the Stretched Lens Array Squarerigger (SLASR) for Space," 25th International Symposium on Space Technology and Science, Kanzawaa, Japan, ISTS 2006-r-1-23, Jun. 2006.

15. Stella, P.M., Davis, G.L., Mueller, R.L., Krut, D., Brinker, D., and Scheiman, D.A., "The performance of advanced solar cells for interplanetary missions," 28th IEEE Photovoltaic Specialists Conference, Sept. 2000. 
16. Stella, P.M., Pool, F.S., Nicolet, M.A., and Iles, P.A., "PV Technology for Low Intensity, Low Temperature (LILT) Applications," 1st World Conference on Photovoltaic Energy Conversion, Dec. 1994.

17. Mueller, R.L., and Gaddy, E., "The Performance of Advanced III-V Solar Cells," 29th IEEE Photovoltaic Specialists Conference, May 2002.

18. Fatermi, N.S., Stella, P., et al., "Performance of high-efficiency advanced triple-junction solar panels for the LILT Mission Dawn," 20th EU-PVSEC; Jun. 2005.

19. Stella, P., Mueller, R., Davis, G., and Distefano, S., "The Environmental Performance at Low Intensity, Low Temperature (LILT) of High Efficiency Triple Junction Solar Cells," 2nd International Energy Conversion Engineering Conference, Aug. 2004.

20. Scheiman, D.A., Jenkins, P.P., Brinker, D.J., and Appelbaum, J., "Low Intensity Low Temperature (LILT) Measurements and Coefficients on New Photovoltaic Structures," Space Photovoltaic Research and Technology 1995, NASA CP-10180, Oct. 1995.

21. Piszczor, M.F., Benson, S.W., Scheiman, D.A., Snyder, D.B., Fincannon, H.J., Oleson, S.R., and Landis, G.A., "Advanced Solar Cell and Array Technology for NASA Deep Space Missions," 33rd IEEE Photovoltaic Specialists Conference, May 2008.

22. Jensen, H., and Laursen, J., "Power Conditioning Unit for Rosetta/Mars Express," European Space Agency Publications-SP 2002, vol. 502, pp. 249-256, 2002.

23. Shaltens, R.K., and Wong, W.A., "Advanced Stirling Technology Development at NASA Glenn Research Center," NASA/TM-2007-214930, Sept. 2007.

24. Esper, J., "The Neptune/Triton Explorer mission: A concept feasibility study," Acta Astronautica, vol. 59, Selected Proceedings of the Fifth IAA International Conference on Low Cost Planetary Missions, pp. 627-637, Oct.-Dec. 2006.

25. Shenai, K., "New millennium ultralow power microsystems," Proceedings of the IEEE National Aerospace and Electronics Conference 2000, pp. 459-468.

26. Speer, D., Jackson, G., and Raphael, D., "Flight computer design for the Space Technology 5 (ST-5) mission," IEEE Aerospace Conference Proceedings, 2002, vol. 1, pp. 255-269.

27. Alkalai, L., "Advanced Microelectronics Technologies for Future Small Satellite Systems," 2nd IAA Symposium on Small Satellites for Earth Observation, Apr.1999.

28. Rayman, M., and Lehman, D., "Deep Space One: NASA's First Deep-Space Technology Validation Mission," Acta Astronautica, vol. 41, no. 4, pp. 289-299, 1997. 


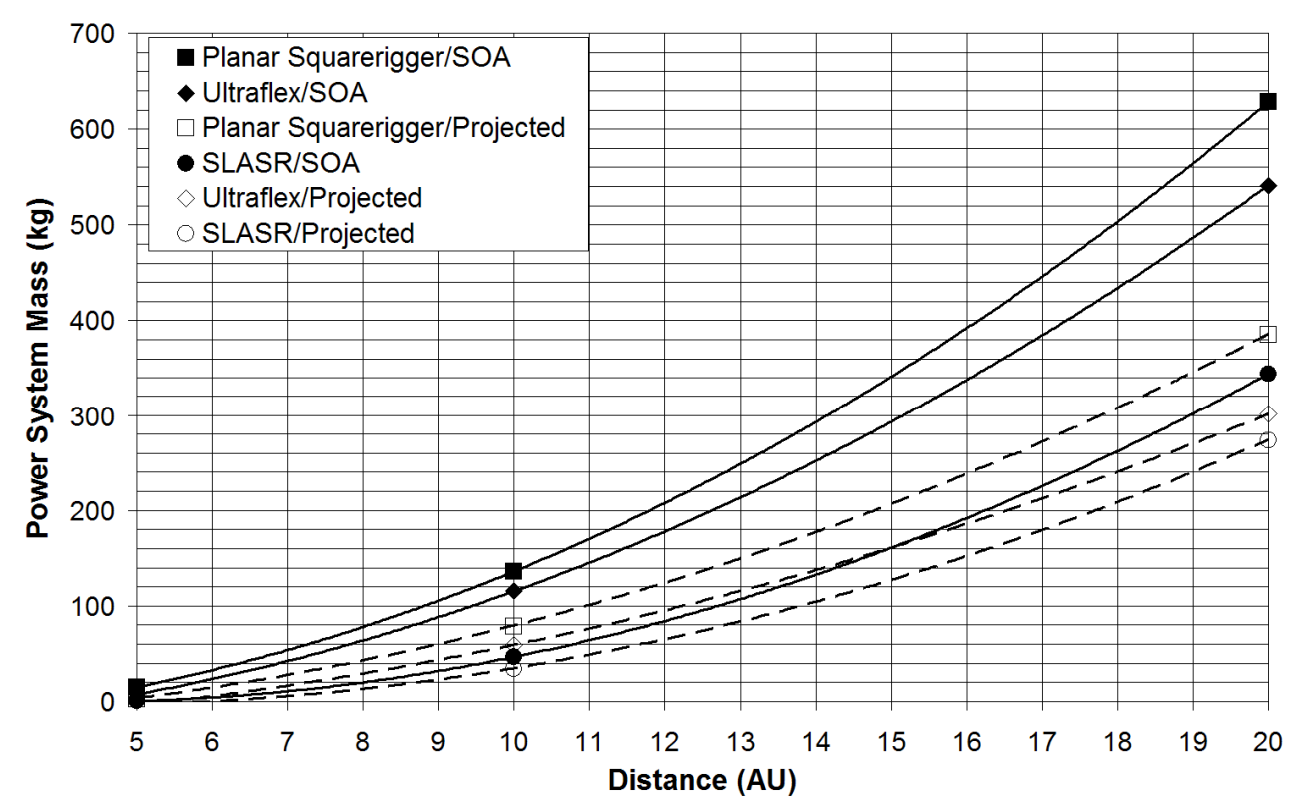

Figure 1.-Mass increase due to solar power to replace one ASRG RPS unit.

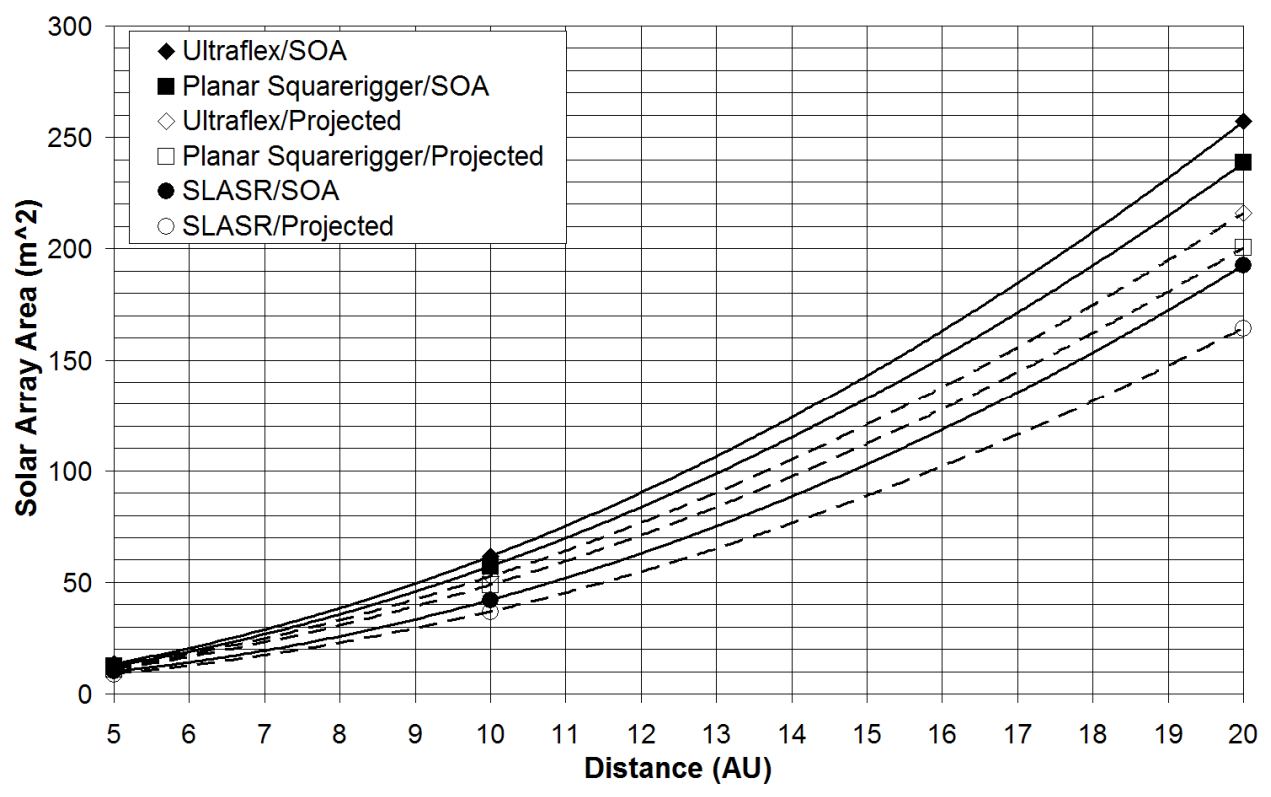

Figure 2.-Area increase due to solar power to replace one ASRG RPS unit. 


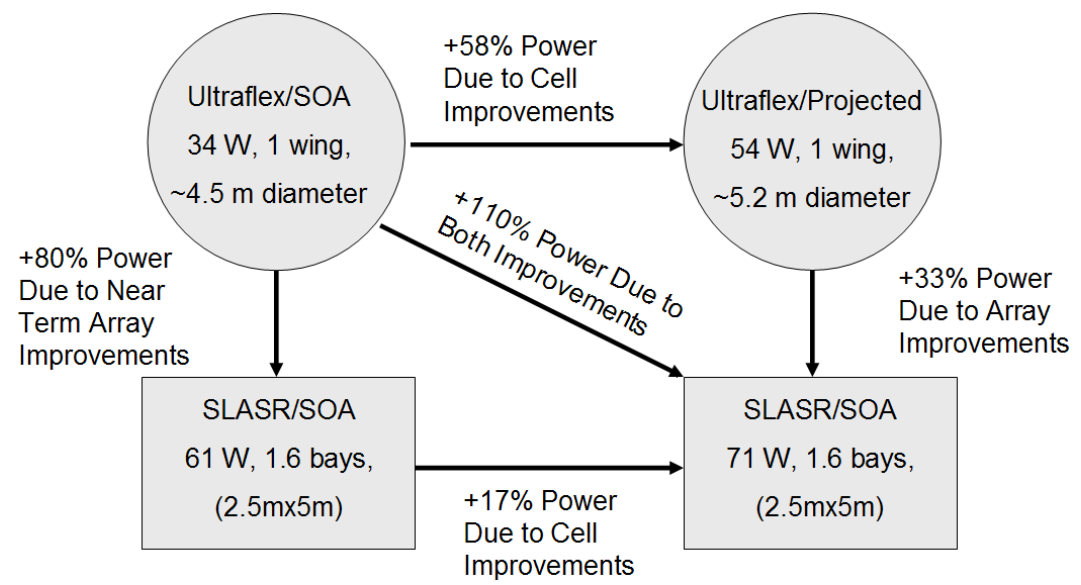

Figure 3.-Equal mass comparison of one ASRG power system with various solar power system options based on array/cell power improvements through technology development at Saturn flyby location (note: one ASRG power system produces $133 \mathrm{~W}$ using $\sim 1 \mathrm{~kg}$ of plutonium-238). 


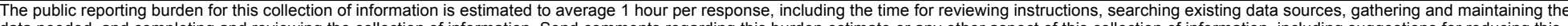

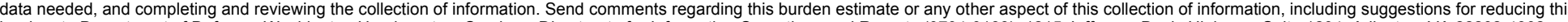

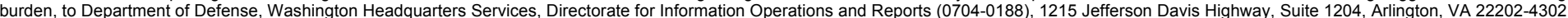

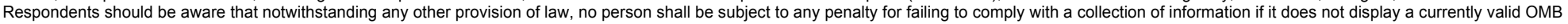
control number.

PLEASE DO NOT RETURN YOUR FORM TO THE ABOVE ADDRESS
1. REPORT DATE (DD-MM-YYYY)
2. REPORT TYPE
3. DATES COVERED (From - To)

01-10-2008

Technical Memorandum

\section{TITLE AND SUBTITLE}

Radioisotope Reduction Using Solar Power for Outer Planetary Missions

\section{5a. CONTRACT NUMBER}

5b. GRANT NUMBER

5c. PROGRAM ELEMENT NUMBER

5d. PROJECT NUMBER

Fincannon, James

\section{5e. TASK NUMBER}

5f. WORK UNIT NUMBER

WBS 342806.06.03.03

\section{PERFORMING ORGANIZATION REPORT NUMBER}

E-16607

National Aeronautics and Space Administration

John H. Glenn Research Center at Lewis Field

Cleveland, Ohio 44135-3191

9. SPONSORING/MONITORING AGENCY NAME(S) AND ADDRESS(ES)

National Aeronautics and Space Administration

Washington, DC 20546-0001

10. SPONSORING/MONITORS
ACRONYM(S)
NASA
11. SPONSORING/MONITORING
REPORT NUMBER
NASA/TM-2008-215437

\section{DISTRIBUTION/AVAILABILITY STATEMENT}

Unclassified-Unlimited

Subject Categories: 20 and 91

Available electronically at http://gltrs.grc.nasa.gov

This publication is available from the NASA Center for AeroSpace Information, 301-621-0390

\section{SUPPLEMENTARY NOTES}

\section{ABSTRACT}

Radioisotope power systems have historically been (and still are) the power system of choice from a mass and size perspective for outer planetary missions. High demand for and limited availability of radioisotope fuel has made it necessary to investigate alternatives to this option. Low mass, high efficiency solar power systems have the potential for use at low outer planetary temperatures and illumination levels. This paper documents the impacts of using solar power systems instead of radioisotope power for all or part of the power needs of outer planetary spacecraft and illustrates the potential fuel savings of such an approach.

\section{SUBJECT TERMS}

Spacecraft power; Radioisotope fuel; Radioisotope power systems; Solar energy; Solar power; Solar arrays; Outer planets; Computer program; Algorithms

\begin{tabular}{|c|c|c|c|c|}
\hline \multicolumn{3}{|c|}{ 16. SECURITY CLASSIFICATION OF: } & \multirow{2}{*}{$\begin{array}{l}\text { 17. LIMITATION OF } \\
\text { ABSTRACT } \\
\text { UU }\end{array}$} & \multirow{2}{*}{$\begin{array}{l}\text { 18. NUMBER } \\
\text { OF } \\
\text { PAGES } \\
15\end{array}$} \\
\hline $\begin{array}{l}\text { a. REPORT } \\
\text { U }\end{array}$ & $\begin{array}{l}\text { b. ABSTRACT } \\
\text { U }\end{array}$ & $\begin{array}{l}\text { c. THIS } \\
\text { PAGE } \\
U\end{array}$ & & \\
\hline
\end{tabular}



